\title{
A Thermodynamic Analysis on the Roasting of Pyrite
}

\author{
Yan Zhang, Qian Li *, Xiaoliang Liu ${ }^{\circ}$, Bin $\mathrm{Xu}$ *, Yongbin Yang and Tao Jiang \\ School of Minerals Processing and Bioengineering, Central South University, Changsha 410083, China; \\ yanzhang27@csu.edu.cn (Y.Z.); xiaoliang.liu@csu.edu.cn (X.L.); ybyang@126.com (Y.Y.); \\ jiangtao@csu.edu.cn (T.J.) \\ * Correspondence: csuliqian208018@csu.edu.cn (Q.L.); xubincsu@csu.edu.cn (B.X.)
}

Received: 2 March 2019; Accepted: 5 April 2019; Published: 8 April 2019

\begin{abstract}
A series of thermodynamic calculations are performed for the roasting of pyrite in changing temperatures and atmospheres. The relationship between $\Delta_{\mathrm{r}} \mathrm{G}^{\theta}$ and temperature in the range of $\mathrm{T}=300-1200 \mathrm{~K}$ shows that, depending on the atmosphere it is in, reactions of pyrolysis, oxidation or reduction can occur. Both the pyrolysis of pyrite in an inert atmosphere and its oxidation by oxygen can form pyrrhotite (mainly $\mathrm{Fe}_{0.875} \mathrm{~S}$ and $\mathrm{FeS}$ ), but the temperature required for oxidation is much lower than that for pyrolysis. In an oxygen-containing atmosphere, the isothermal predominance areas for the $\mathrm{Fe}-\mathrm{S}-\mathrm{O}$ system indicate that a change in temperature and oxygen partial pressure can lead the pyrite to undergo desulphurization to pyrrhotite $\left(\mathrm{FeS}_{2} \rightarrow \mathrm{Fe}_{0.875} \mathrm{~S} / \mathrm{FeS}\right)$ or iron oxides $\left(\mathrm{FeS}_{2} \rightarrow\right.$ $\left.\mathrm{Fe}_{3} \mathrm{O}_{4} / \mathrm{Fe}_{2} \mathrm{O}_{3}\right)$, or sulphation to iron sulphates $\left(\mathrm{FeS}_{2} \rightarrow \mathrm{FeSO}_{4} / \mathrm{Fe}_{2}\left(\mathrm{SO}_{4}\right)_{3}\right)$. The presence of carbon is beneficial to the desulphurization of pyrite under an oxidizing atmosphere since iron sulphates can be converted to iron oxides at very low levels of $\mathrm{P}_{\mathrm{CO}} / \mathrm{P}_{\mathrm{CO} 2}$. Results presented in this paper offer theoretical guidance for the optimization of roasting of pyrite for different purposes.
\end{abstract}

Keywords: pyrite roasting; thermodynamic analysis; predominance areas; pyrolysis; desulphurization; sulphation

\section{Introduction}

Pyrite $\left(\mathrm{FeS}_{2}\right)$ is one of the most common and widely distributed sulphide minerals [1]. In industry, pyrite is a chief raw material to produce sulphur, sulphur dioxide and sulphuric acid. Also, pyrite is usually found in association with valuable metallic elements such as $\mathrm{Au}, \mathrm{Ag}$ and $\mathrm{Cu}$ that can be recovered in a comprehensive utilization of resources [2]. In terms of the auriferous pyrite (i.e., sulfidic gold ore), gold often occurs as submicroscopic particles that are easily enclosed in crystal lattices of pyrite [3]. Consequently, gold is difficult to be exposed unless undergoing ultrafine grinding, resulting in high energy consumption [4]. Gold is also sometimes associated with pyrite and preg-robbing carbonaceous matters (mainly carbon) that readily adsorb gold complexes from the leach solution. Under such a circumstance, carbonaceous sulphide gold ores that are regarded as the most refractory ores [5] emerge and render their gold extraction challenging. Pretreatments are thus necessary for improving the gold extraction from this type of refractory gold ores.

Oxidative roasting of carbonaceous sulphide gold ores has currently been one of the most widespread and effective pretreating methods [6-9]. The effect of oxidative roasting is mainly twofold. On the one hand, as a result of the oxidation of sulphur in pyrite to form sulphur dioxide $\left(\mathrm{SO}_{2}\right)$, porous iron oxides (i.e., $\mathrm{Fe}_{2} \mathrm{O}_{3}$ and $\mathrm{Fe}_{3} \mathrm{O}_{4}$ ) are formed that expose the gold particles locked in pyrite. On the other hand, the oxidation of carbonaceous matter eliminates its preg-robbing effect on leached gold. It is clear that the formation of $\mathrm{SO}_{2}$, hence the subsequent production of sulphuric acid, and the comprehensive recovery of associated valuable metals from pyrite are closely related to the roasting behaviour of pyrite. If carbonaceous matters are also present, the possible impacts of carbon $(\mathrm{C})$ or its oxides $\left(\mathrm{CO}\right.$ and $\left.\mathrm{CO}_{2}\right)$ on the roasting of pyrite should also be taken into consideration. 
Experimentally, the roasting behaviours of pyrite have been studied by a number of researchers. Dunn and De $[10,11]$ investigated the effect of temperature and atmosphere on the oxidation of pyrite in different particle size ranges by differential thermal analysis (DTA) and thermogravimetric analysis (TGA). It was observed that pyrite less than $0.045 \mathrm{~mm}$ in size could be directly and completely oxidized to hematite at $776 \mathrm{~K}$ in an air atmosphere. In the size range of $0.09-0.125 \mathrm{~mm}$ and under an air atmosphere, hematite formed at temperatures lower than $788 \mathrm{~K}$ whilst pyrrhotite formed at temperatures higher than $788 \mathrm{~K}$. With increasing partial oxygen pressure in the atmosphere, the oxidation of pyrite was enhanced significantly even at relatively low temperatures and iron sulphates $\left(\mathrm{Fe}_{2}\left(\mathrm{SO}_{4}\right)_{3}\right.$ and $\left.\mathrm{FeSO}_{4}\right)$ were easily produced. Similarly, by means of DTA and TGA, Jorgensen and Moyle [12] studied the phase transformation of pyrite for its oxidation in air in the particle size $0.053-0.074 \mathrm{~mm}$. It was found that the pyrite surface was transformed into hematite at $702 \mathrm{~K}$ and pyrrhotite at $850 \mathrm{~K}$, but with the temperature increasing to $881 \mathrm{~K}$ and $942 \mathrm{~K}$, the resultant species were ferrous sulphate and ferric sulphate, respectively. The X-ray diffraction (XRD) analysis conducted by Schorr and Everhart [13] proved that the oxidation of pyrite in air with a low heating rate up to a temperature of $753 \mathrm{~K}$ in a furnace took place in a direct oxidation way to form iron oxides. The technique of Mössbauer spectroscopy used in the work of Prasad et al. [14] showed that pyrrhotite was detected after roasting pyrite in air at a temperature of $883 \mathrm{~K}$. The roasting of pyrite was further investigated in a gas mixture of $\mathrm{CO}_{2}$ and $\mathrm{O}_{2}$ by Hong and Fegley [15], revealing that both pyrrhotite and hematite were formed at a temperature range $665-733 \mathrm{~K}$ while only pyrrhotite was found when the temperature was controlled in the range $757-811 \mathrm{~K}$.

The roasting of pyrite is intimately associated with the process variables such as temperature, atmosphere and mineral particle size. In different research, various roasting reactions and phase transformations of pyrite occur under different reaction conditions. Distinctly, no comprehensive and definite information on the possible reactions with the corresponding conditions has been offered for the roasting of pyrite.

Thermodynamic analysis can provide significant information on the possibility of chemical reactions that may occur, pyrometallurgical conditions relevant to the predominance area of mineral phase, and phase transformations of mineral during the roasting process. Few endeavours have recently focused on studying the roasting behaviour of pyrite from systematic thermodynamic calculations. The thermodynamic modelling of Fe-S system was studied by Waldner and Pelton [16], but little information was involved for the roasting of pyrite. The effects of $\mathrm{CO}$, mixture of $\mathrm{CO}$ and $\mathrm{CO}_{2}$, and solid $\mathrm{C}$ on the thermodynamic behaviour of arsenopyrite (FeAsS) were researched by Chakraborti and Lynch [17]. The roasting of pyrite in the presence of $\mathrm{C}$ or $\mathrm{CO}$, however, has seldom been researched by thermodynamic analysis.

This paper uses thermodynamic calculations to analyse the roasting behaviour of pyrite. The possible involved chemical reactions are discussed. The effect of roasting temperature and atmosphere on the pyrolysis and oxidation of pyrite as well as that of carbon on the roasting of pyrite are also studied. It can provide a theoretical basis to better understand and guide the optimization of the roasting of pyrite for a specific purpose.

\section{A Preliminary Analysis of Possible Chemical Reactions during the Roasting of Pyrite}

Under different roasting conditions, pyrite can be transformed to a variety of solid phases such as pyrrhotite $\left(\mathrm{Fe}_{1-x} \mathrm{~S}\right.$, mainly $\mathrm{Fe}_{0.875} \mathrm{~S}$ or $\mathrm{FeS}$ which is the commonest form [16,18]), magnetite $\left(\mathrm{Fe}_{3} \mathrm{O}_{4}\right)$, hematite $\left(\mathrm{Fe}_{2} \mathrm{O}_{3}\right)$, ferrous sulphate $\left(\mathrm{FeSO}_{4}\right)$ and ferric sulphate $\left(\mathrm{Fe}_{2}\left(\mathrm{SO}_{4}\right)_{3}\right)$, and gas phases such as sulphur vapour $\left(\mathrm{S}_{2}\right)$ and sulphur dioxide $\left(\mathrm{SO}_{2}\right)$. In the presence of $\mathrm{C}$ or other phases such as $\mathrm{CaO}$, $\mathrm{MgO}$ and $\mathrm{Al}_{2} \mathrm{O}_{3}$, various reduction reactions by $\mathrm{C} / \mathrm{CO}$ or sulphur-fixation reactions can also take place. According to the relevant species of reactants and resultants, 45 possible chemical reactions can be deduced as listed in Table 1. They can be divided into mainly three categories: (i) pyrolysis in an inert atmosphere (Equations (1),(2)), (ii) oxidation by $\mathrm{O}_{2}$ (Equations (3)-(30)) and (iii) reduction by $\mathrm{C}$ or $\mathrm{CO}$ (Equations (31)-(45)). In addition, based on the standard Gibbs free energies of formation for species 
$\left(\Delta_{\mathrm{f}} \mathrm{G}^{\theta}, \mathrm{kJ} \cdot \mathrm{mol}^{-1}\right)$ at different temperatures $(\mathrm{T}=300-1200 \mathrm{~K})$, the corresponding $\Delta_{\mathrm{r}} \mathrm{G}^{\theta}$ for each reaction can be obtained as a function of $\Delta_{\mathrm{r}} \mathrm{G}^{\theta}$ and $\mathrm{T}$ (listed in Table 1). The variation of $\Delta_{\mathrm{r}} \mathrm{G}^{\theta}$ with $\mathrm{T}$ for the possible reactions is also clearly depicted in Figure 1. Thermodynamically, $\Delta_{\mathrm{r}} \mathrm{G}^{\theta}>0$ means that a chemical reaction cannot occur; on the contrary $\left(\Delta_{\mathrm{r}} \mathrm{G}^{\theta}<0\right)$, the reaction will spontaneously occur, and the more negative the $\Delta_{\mathrm{r}} \mathrm{G}^{\theta}$ value is, the more easily the reaction takes place.

Table 1. Possible chemical reactions and corresponding $\Delta_{\mathrm{r}} \mathrm{G}^{\theta}$ at temperatures of $300-1200 \mathrm{~K}$ *

\begin{tabular}{|c|c|c|}
\hline Reaction & $\Delta_{\mathrm{r}} \mathrm{G}^{\theta},\left(\mathrm{kJ} \cdot \mathrm{mol}^{-1}\right)$ & No. \\
\hline \multicolumn{2}{|l|}{ Pyrolysis } & $\mathrm{i}$ \\
\hline $\mathrm{FeS}_{2}=8 / 7 \mathrm{Fe}_{0.875} \mathrm{~S}+3 / 7 \mathrm{~S}_{2}(\mathrm{~g})$ & $-0.1219 \mathrm{~T}+109.0817$ & (1) \\
\hline $\mathrm{FeS}_{2}=\mathrm{FeS}+\frac{1}{2} \mathrm{~S}_{2}(\mathrm{~g})$ & $-0.1375 \mathrm{~T}+140.2344$ & (2) \\
\hline \multicolumn{2}{|l|}{ Oxidation by $\mathrm{O}_{2}$} & ii \\
\hline $\mathrm{S}_{2}(\mathrm{~g})+2 \mathrm{O}_{2}(\mathrm{~g})=2 \mathrm{SO}_{2}(\mathrm{~g})$ & $0.1465 \mathrm{~T}-723.7860$ & (3) \\
\hline $\mathrm{FeS}_{2}+\mathrm{O}_{2}(\mathrm{~g})=\mathrm{FeS}+\mathrm{SO}_{2}(\mathrm{~g})$ & $-0.0647 \mathrm{~T}-221.4677$ & (4) \\
\hline $\mathrm{FeS}_{2}+6 / 7 \mathrm{O}_{2}(\mathrm{~g})=8 / 7 \mathrm{Fe}_{0.875} \mathrm{~S}+6 / 7 \mathrm{SO}_{2}(\mathrm{~g})$ & $-0.0592 \mathrm{~T}-201.0982$ & (5) \\
\hline $\mathrm{Fe}_{0.875} \mathrm{~S}+1 / 8 \mathrm{O}_{2}(\mathrm{~g})=7 / 8 \mathrm{FeS}+1 / 8 \mathrm{SO}_{2}(\mathrm{~g})$ & $-0.0038 \mathrm{~T}-18.0233$ & (6) \\
\hline $\mathrm{FeS}_{2}+11 / 4 \mathrm{O}_{2}(\mathrm{~g})=1 / 2 \mathrm{Fe}_{2} \mathrm{O}_{3}+2 \mathrm{SO}_{2}(\mathrm{~g})$ & $0.0756 \mathrm{~T}-832.7516$ & (7) \\
\hline $\mathrm{FeS}_{2}+8 / 3 \mathrm{O}_{2}(\mathrm{~g})=1 / 3 \mathrm{Fe}_{3} \mathrm{O}_{4}+2 \mathrm{SO}_{2}(\mathrm{~g})$ & $0.0519 \mathrm{~T}-792.2288$ & (8) \\
\hline $\mathrm{FeS}+5 / 3 \mathrm{O}_{2}(\mathrm{~g})=1 / 3 \mathrm{Fe}_{3} \mathrm{O}_{4}+\mathrm{SO}_{2}(\mathrm{~g})$ & $0.1166 \mathrm{~T}-570.7611$ & (9) \\
\hline $\mathrm{FeS}+7 / 4 \mathrm{O}_{2}(\mathrm{~g})=1 / 2 \mathrm{Fe}_{2} \mathrm{O}_{3}+\mathrm{SO}_{2}(\mathrm{~g})$ & $0.1407 \mathrm{~T}-611.2840$ & (10) \\
\hline $\mathrm{Fe}_{0.875} \mathrm{~S}+19 / 12 \mathrm{O}_{2}(\mathrm{~g})=7 / 24 \mathrm{Fe}_{3} \mathrm{O}_{4}+\mathrm{SO}_{2}(\mathrm{~g})$ & $0.0985 \mathrm{~T}-518.6612$ & (11) \\
\hline $\mathrm{Fe}_{0.875} \mathrm{~S}+53 / 32 \mathrm{O}_{2}(\mathrm{~g})=7 / 16 \mathrm{Fe}_{2} \mathrm{O}_{3}+\mathrm{SO}_{2}(\mathrm{~g})$ & $0.1192 \mathrm{~T}-553.6720$ & (12) \\
\hline $\mathrm{Fe}_{3} \mathrm{O}_{4}+1 / 4 \mathrm{O}_{2}(\mathrm{~g})=3 / 2 \mathrm{Fe}_{2} \mathrm{O}_{3}$ & $0.0722 \mathrm{~T}-121.5684$ & (13) \\
\hline $\mathrm{FeS}_{2}+3 \mathrm{O}_{2}(\mathrm{~g})=\mathrm{FeSO}_{4}+\mathrm{SO}_{2}(\mathrm{~g})$ & $0.2920 \mathrm{~T}-1050.5365$ & (14) \\
\hline $\mathrm{FeS}_{2}+7 / 2 \mathrm{O}_{2}(\mathrm{~g})=1 / 2 \mathrm{Fe}_{2}\left(\mathrm{SO}_{4}\right)_{3}+1 / 2 \mathrm{SO}_{2}(\mathrm{~g})$ & $0.4859 \mathrm{~T}-1265.3779$ & (15) \\
\hline $\mathrm{FeS}+2 \mathrm{O}_{2}(\mathrm{~g})=\mathrm{FeSO}_{4}$ & $0.3566 \mathrm{~T}-829.0689$ & (16) \\
\hline $\mathrm{FeS}+5 / 2 \mathrm{O}_{2}(\mathrm{~g})+1 / 2 \mathrm{SO}_{2}(\mathrm{~g})=1 / 2 \mathrm{Fe}_{2}\left(\mathrm{SO}_{4}\right)_{3}$ & $0.5505 \mathrm{~T}-1043.9102$ & (17) \\
\hline $\mathrm{Fe}_{0.875} \mathrm{~S}+\mathrm{O}_{2}(\mathrm{~g})=7 / 8 \mathrm{FeSO}_{4}+1 / 8 \mathrm{SO}_{2}(\mathrm{~g})$ & $0.3099 \mathrm{~T}-744.6433$ & (18) \\
\hline $\mathrm{Fe}_{0.875} \mathrm{~S}+47 / 16 \mathrm{O}_{2}(\mathrm{~g})=7 / 16 \mathrm{Fe}_{2}\left(\mathrm{SO}_{4}\right)_{3}+5 / 16 \mathrm{SO}_{2}(\mathrm{~g})$ & $0.4938 \mathrm{~T}-1127.0820$ & (19) \\
\hline $\mathrm{Fe}_{3} \mathrm{O}_{4}+\mathrm{O}_{2}(\mathrm{~g})+3 \mathrm{SO}_{2}(\mathrm{~g})=3 \mathrm{FeSO}_{4}$ & $0.7201 \mathrm{~T}-774.9232$ & (20) \\
\hline $\mathrm{Fe}_{3} \mathrm{O}_{4}+5 / 2 \mathrm{O}_{2}(\mathrm{~g})+9 / 2 \mathrm{SO}_{2}(\mathrm{~g})=3 / 2 \mathrm{Fe}_{2}\left(\mathrm{SO}_{4}\right)_{3}$ & $1.3018 \mathrm{~T}-1419.4472$ & (21) \\
\hline $\mathrm{Fe}_{2} \mathrm{O}_{3}+1 / 2 \mathrm{O}_{2}(\mathrm{~g})+2 \mathrm{SO}_{2}(\mathrm{~g})=2 \mathrm{FeSO}_{4}$ & $0.4319 \mathrm{~T}-435.5699$ & (22) \\
\hline $\mathrm{Fe}_{2} \mathrm{O}_{3}+3 / 2 \mathrm{O}_{2}(\mathrm{~g})+3 \mathrm{SO}_{2}(\mathrm{~g})=\mathrm{Fe}_{2}\left(\mathrm{SO}_{4}\right)_{3}$ & $0.8197 \mathrm{~T}-865.2525$ & (23) \\
\hline $\mathrm{FeSO}_{4}+1 / 2 \mathrm{O}_{2}(\mathrm{~g})+1 / 2 \mathrm{SO}_{2}(\mathrm{~g})=1 / 2 \mathrm{Fe}_{2}\left(\mathrm{SO}_{4}\right)_{3}$ & $0.1939 \mathrm{~T}-214.8413$ & (24) \\
\hline $\mathrm{CaO}+1 / 2 \mathrm{O}_{2}(\mathrm{~g})+\mathrm{SO}_{2}(\mathrm{~g})=\mathrm{CaSO}_{4}$ & $0.2705 \mathrm{~T}-500.7193$ & (25) \\
\hline $\mathrm{MgO}+1 / 2 \mathrm{O}_{2}(\mathrm{~g})+\mathrm{SO}_{2}(\mathrm{~g})=\mathrm{MgSO}_{4}$ & $0.2758 \mathrm{~T}-358.8132$ & (26) \\
\hline $\mathrm{Al}_{2} \mathrm{O}_{3}+3 / 2 \mathrm{O}_{2}(\mathrm{~g})+3 \mathrm{SO}_{2}(\mathrm{~g})=\mathrm{Al}_{2}\left(\mathrm{SO}_{4}\right)_{3}$ & $0.8174 \mathrm{~T}-854.7974$ & (27) \\
\hline $\mathrm{C}+\mathrm{O}_{2}(\mathrm{~g})=\mathrm{CO}_{2}(\mathrm{~g})$ & $-0.0019 \mathrm{~T}-393.9486$ & (28) \\
\hline $\mathrm{C}+1 / 2 \mathrm{O}_{2}(\mathrm{~g})=\mathrm{CO}(\mathrm{g})$ & $-0.0896 \mathrm{~T}-110.6684$ & (29) \\
\hline $\mathrm{CO}(\mathrm{g})+1 / 2 \mathrm{O}_{2}(\mathrm{~g})=\mathrm{CO}_{2}(\mathrm{~g})$ & $0.0877 \mathrm{~T}-283.2802$ & (30) \\
\hline \multicolumn{2}{|l|}{ Reduction by $\mathrm{C}$ or $\mathrm{CO}$} & iii \\
\hline $\mathrm{C}+\mathrm{CO}_{2}(\mathrm{~g})=2 \mathrm{CO}(\mathrm{g})$ & $-0.1772 \mathrm{~T}+172.6118$ & (31) \\
\hline $\mathrm{FeS}_{2}+\mathrm{CO}(\mathrm{g})=\mathrm{FeS}+\mathrm{COS}(\mathrm{g})$ & $-0.0581 \mathrm{~T}+48.5353$ & (32) \\
\hline $\mathrm{FeS}_{2}+6 / 7 \mathrm{CO}(\mathrm{g})=8 / 7 \mathrm{Fe}_{0.875} \mathrm{~S}+6 / 7 \mathrm{COS}(\mathrm{g})$ & $-0.0534 \mathrm{~T}+30.2428$ & (33) \\
\hline $\mathrm{S}_{2}(\mathrm{~g})+2 \mathrm{CO}(\mathrm{g})=2 \operatorname{COS}(\mathrm{g})$ & $0.1587 \mathrm{~T}-183.3983$ & (34) \\
\hline $\mathrm{Fe}_{2} \mathrm{O}_{3}+1 / 3 \mathrm{C}=2 / 3 \mathrm{Fe}_{3} \mathrm{O}_{4}+1 / 3 \mathrm{CO}(\mathrm{g})$ & $-0.0780 \mathrm{~T}+44.1562$ & (35) \\
\hline $\mathrm{Fe}_{2} \mathrm{O}_{3}+1 / 3 \mathrm{CO}(\mathrm{g})=2 / 3 \mathrm{Fe}_{3} \mathrm{O}_{4}+1 / 3 \mathrm{CO}_{2}(\mathrm{~g})$ & $-0.0189 \mathrm{~T}-13.3811$ & (36) \\
\hline $\mathrm{FeSO}_{4}+1 / 4 \mathrm{C}=1 / 2 \mathrm{Fe}_{2} \mathrm{O}_{3}+1 / 4 \mathrm{CO}_{2}(\mathrm{~g})+\mathrm{SO}_{2}(\mathrm{~g})$ & $-0.2164 \mathrm{~T}+119.2978$ & (37) \\
\hline $\mathrm{FeSO}_{4}+1 / 2 \mathrm{CO}(\mathrm{g})=1 / 2 \mathrm{Fe}_{2} \mathrm{O}_{3}+1 / 2 \mathrm{CO}_{2}(\mathrm{~g})+\mathrm{SO}_{2}(\mathrm{~g})$ & $-0.1721 \mathrm{~T}+76.1448$ & (38) \\
\hline $\mathrm{FeSO}_{4}+1 / 3 \mathrm{C}=1 / 3 \mathrm{Fe}_{3} \mathrm{O}_{4}+1 / 3 \mathrm{CO}_{2}(\mathrm{~g})+\mathrm{SO}_{2}(\mathrm{~g})$ & $-0.2407 \mathrm{~T}+126.9915$ & (39) \\
\hline $\mathrm{FeSO}_{4}+2 / 3 \mathrm{CO}(\mathrm{g})=1 / 3 \mathrm{Fe}_{3} \mathrm{O}_{4}+2 / 3 \mathrm{CO}_{2}(\mathrm{~g})+\mathrm{SO}_{2}(\mathrm{~g})$ & $-0.1816 \mathrm{~T}+69.4543$ & (40) \\
\hline $\mathrm{Fe}_{2}\left(\mathrm{SO}_{4}\right)_{3}+3 / 2 \mathrm{C}=\mathrm{Fe}_{2} \mathrm{O}_{3}+3 / 2 \mathrm{CO}_{2}(\mathrm{~g})+3 \mathrm{SO}_{2}(\mathrm{~g})$ & $-0.8225 \mathrm{~T}+274.3296$ & (41) \\
\hline $\mathrm{Fe}_{2}\left(\mathrm{SO}_{4}\right)_{3}+3 \mathrm{CO}(\mathrm{g})=\mathrm{Fe}_{2} \mathrm{O}_{3}+3 \mathrm{CO}_{2}(\mathrm{~g})+3 \mathrm{SO}_{2}(\mathrm{~g})$ & $-0.5567 \mathrm{~T}+15.4119$ & (42) \\
\hline $\mathrm{Fe}_{2}\left(\mathrm{SO}_{4}\right)_{3}+5 / 3 \mathrm{C}=2 / 3 \mathrm{Fe}_{3} \mathrm{O}_{4}+5 / 3 \mathrm{CO}_{2}(\mathrm{~g})+3 \mathrm{SO}_{2}(\mathrm{~g})$ & $-0.8710 \mathrm{~T}+289.7172$ & (43) \\
\hline $\mathrm{Fe}_{2}\left(\mathrm{SO}_{4}\right)_{3}+10 / 3 \mathrm{CO}(\mathrm{g})=2 / 3 \mathrm{Fe}_{3} \mathrm{O}_{4}+10 / 3 \mathrm{CO}_{2}(\mathrm{~g})+3 \mathrm{SO}_{2}(\mathrm{~g})$ & $-0.5756 \mathrm{~T}+2.0308$ & (44) \\
\hline $\mathrm{Fe}_{2}\left(\mathrm{SO}_{4}\right)_{3}+2 \mathrm{CO}(\mathrm{g})=2 \mathrm{FeSO}_{4}+2 \mathrm{CO}_{2}(\mathrm{~g})+\mathrm{SO}_{2}(\mathrm{~g})$ & $-0.2125 \mathrm{~T}-136.8778$ & (45) \\
\hline
\end{tabular}

* $\Delta_{\mathrm{r}} \mathrm{G}^{\theta}=\sum\left[\left( \pm v_{i}\right) \Delta_{\mathrm{f}} \mathrm{G}_{i}{ }^{\theta}\right]$, of which $v_{i}$ is the stoichiometric ratio of reactants $\left(-v_{i}\right)$ and resultants $\left(+v_{i}\right)$, and $\Delta_{\mathrm{f}} \mathrm{G}_{i}{ }^{\theta}$ of all species were based on the thermochemical data of pure substances from Barin [19]. 
As shown in Table 1 and Figure 1, the pyrolysis of pyrite to sulphur vapour $\left(\mathrm{S}_{2}\right)$ and pyrrhotite $\mathrm{Fe}_{0.875} \mathrm{~S}$ (Equation (1)) or FeS (Equation (2)) can proceed spontaneously only when the temperature exceeds around $900-1000 \mathrm{~K}\left(\Delta_{\mathrm{r}} \mathrm{G}^{\theta}<0\right)$. However, their $\Delta_{\mathrm{r}} \mathrm{G}^{\theta}$ values are slightly negative even at temperatures $>1000 \mathrm{~K}$, indicating that the pyrite pyrolysis is thermodynamically difficult to occur. The kinetic observations from Lambert et al. [20] and Boyabat et al. [21] suggested that the rate-controlling step of pyrite pyrolysis in an inert atmosphere was the desorption of $\mathrm{S}_{2}$ from the pyrite surface. However, under an oxygen-containing atmosphere, the oxidation of $\mathrm{S}_{2}$ by $\mathrm{O}_{2}$ to volatile $\mathrm{SO}_{2}$ (Equation (3)) is apt to take place due to its rather negative $\Delta_{\mathrm{r}} \mathrm{G}^{\theta}$ as presented in Figure 1 . Not surprisingly, with the formation of $\mathrm{SO}_{2}$, pyrite is readily oxidized by $\mathrm{O}_{2}$ to $\mathrm{FeS}$ (Equation (4)) or $\mathrm{Fe}_{0.875} \mathrm{~S}$ (Equation (5)). Research also found that the oxidation rate of pyrite core to pyrrhotite (FeS) was relatively fast at moderate oxygen concentration levels (e.g., $5 \mathrm{vol} \%$ of $\mathrm{O}_{2}$ ) [22]. It can thus be considered that, in the presence of $\mathrm{O}_{2}$, pyrite firstly undergoes partial desulphurization to produce pyrrhotite and $S_{2}$ (Equations (1) and (2)), and then the easy oxidation of $S_{2}$ (Equation (3)) occurs with $\mathrm{S}_{2}$ acting as an intermediate in Equations (4) and (5). In addition, $\mathrm{Fe}_{0.875} \mathrm{~S}$ can be further oxidized by $\mathrm{O}_{2}$ to $\mathrm{FeS}$ and $\mathrm{SO}_{2}$ (Equation (6)), although the corresponding $\Delta_{\mathrm{r}} \mathrm{G}^{\theta}$ is much less negative than that from the oxidation of $\mathrm{FeS}_{2}$ to $\mathrm{Fe}_{0.875} \mathrm{~S} / \mathrm{FeS}$.

Table 1 and Figure 1 also show that pyrite and its pyrolysis product ( $\mathrm{FeS}$ or $\mathrm{Fe}_{0.875} \mathrm{~S}$ ) are readily oxidized by $\mathrm{O}_{2}$ to iron oxides (mainly $\mathrm{Fe}_{3} \mathrm{O}_{4}$ and $\mathrm{Fe}_{2} \mathrm{O}_{3}$ ) (Equations (7)-(12)) with rather negative $\Delta_{\mathrm{r}} \mathrm{G}^{\theta}$ values in the order of $\mathrm{FeS}_{2}<<\mathrm{FeS}<\mathrm{Fe}_{0.875} \mathrm{~S}<<0$. The formed $\mathrm{Fe}_{3} \mathrm{O}_{4}$ can be further oxidized to $\mathrm{Fe}_{2} \mathrm{O}_{3}$ (Equation (13)). In addition, the iron sulphates of $\mathrm{Fe}_{2}\left(\mathrm{SO}_{4}\right)_{3}$ and $\mathrm{FeSO}_{4}$ can be generated directly from $\mathrm{FeS}_{2}$ (Equations (14) and (15)) or indirectly from the intermediates such as $\mathrm{FeS} / \mathrm{Fe}_{0.875} \mathrm{~S}$ (Equations (16)-(19)) and $\mathrm{Fe}_{3} \mathrm{O}_{4} / \mathrm{Fe}_{2} \mathrm{O}_{3}$ (Equations (20)-(23)). Most of $\Delta_{\mathrm{r}} \mathrm{G}^{\theta}$ for these sulphation reactions are rather negative. Thermodynamically, the formation of iron sulphates from the iron sulphides (Equations (14)-(19)) tends to be easier than from the iron oxides (Equations (20)-(23)). When the temperature is overhigh $(>1000-1100 \mathrm{~K})$, the sulphation of $\mathrm{Fe}_{3} \mathrm{O}_{4} / \mathrm{Fe}_{2} \mathrm{O}_{3}$ cannot occur spontaneously due to $\Delta_{\mathrm{r}} \mathrm{G}^{\theta}$ $>0$. Moreover, the formation of $\mathrm{Fe}_{2}\left(\mathrm{SO}_{4}\right)_{3}$ is thermodynamically easier than that of $\mathrm{FeSO}_{4}$ from the sulphating roasting of pyrite, and thus $\mathrm{FeSO}_{4}$ can be further oxidized to $\mathrm{Fe}_{2}\left(\mathrm{SO}_{4}\right)_{3}$ as shown in Equation (24). In the presence of some common gangue phases such as $\mathrm{CaO}, \mathrm{MgO}$ and $\mathrm{Al}_{2} \mathrm{O}_{3}$, they are also shown to readily react with $\mathrm{SO}_{2}$ to form sulphates (Equations (25)-(27)), capturing $\mathrm{SO}_{2}$ during the pyrite roasting and thus preventing its release into the atmosphere.

When there are carbonaceous matters, the existence of $\mathrm{C}$ further complicates the conditions of pyrite roasting. $\mathrm{C}$ can be easily oxidized by $\mathrm{O}_{2}$ to $\mathrm{CO}$ and/or $\mathrm{CO}_{2}$ (Equations (28)-(30)), and at temperatures $>1000 \mathrm{~K}, \mathrm{C}$ can also react with $\mathrm{CO}_{2}$ to form $\mathrm{CO}$ (Equation (31)). Thus, various reduction reactions involved with $\mathrm{C}$ or $\mathrm{CO}$ may occur during the roasting of pyrite. As shown by Equations (32) and (33), pyrite can be reduced by $\mathrm{CO}$ to pyrrhotite and oxysulphide (COS) at relatively high temperatures $(>650-850 \mathrm{~K})$ with mildly negative $\Delta_{\mathrm{r}} \mathrm{G}^{\theta}$ values, and an increasing temperature is shown to favour the occurrence of these reduction reactions. $\mathrm{S}_{2}$, apart from being oxidized by $\mathrm{O}_{2}$ (Equation (3)), can also be readily reduced by CO to COS (Equation (34)). Similar with the oxidation of pyrite (Equations (4) and (5)), $S_{2}$ is also likely an intermediate during the reduction of pyrite by $\mathrm{CO}$. However, $\mathrm{COS}$ has been shown to be unstable in the presence of $\mathrm{O}_{2}$, and easily oxidized by $\mathrm{O}_{2}$ to $\mathrm{CO}_{2}$ and $\mathrm{SO}_{2}[23,24]$. It is therefore not difficult to consider that the formation of $\mathrm{COS}$ and its effects are possibly negligible during the pyrite roasting in an $\mathrm{O}_{2}$-containing atmosphere. In addition, as the temperature increases, the presence of $\mathrm{C}$ or $\mathrm{CO}$ is conducive to the reduction of $\mathrm{Fe}_{2} \mathrm{O}_{3}$ to $\mathrm{Fe}_{3} \mathrm{O}_{4}$ (Equations (35) and (36)), iron sulphates to iron oxides (Equations (37)-(44)), and $\mathrm{Fe}_{2}\left(\mathrm{SO}_{4}\right)_{3}$ to $\mathrm{FeSO}_{4}$ (Equation (45)).

Therefore, thermodynamically, various reactions may occur during the roasting of pyrite under different temperatures and atmospheres. The pyrolysis of pyrite is retarded unless at high temperatures (>900-1000 K). In contrast, most reactions of oxidation by $\mathrm{O}_{2}$ and reduction by $\mathrm{C} / \mathrm{CO}$ can proceed spontaneously. With respect to the roasting of an auriferous pyrite to expose gold, the $\mathrm{S}$ is normally expected to be oxidized as $\mathrm{SO}_{2}$ with the formation of porous and insoluble iron oxides instead of 
soluble iron sulphates. The presence of carbonaceous matters may be advantageous to the formation of iron oxides due to the reduction of iron sulphates by $\mathrm{C}$ or $\mathrm{CO}$, which will be discussed later.

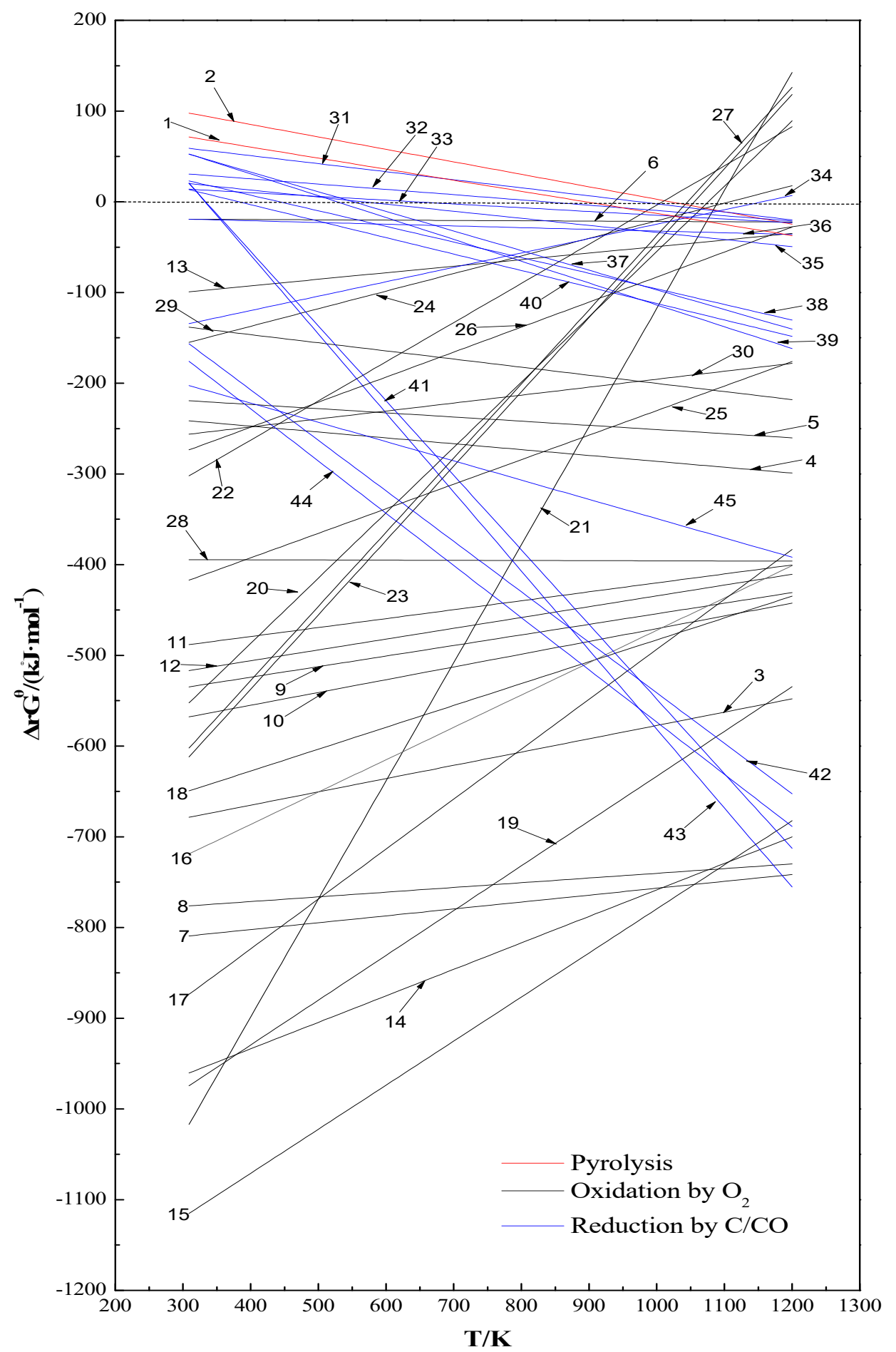

Figure 1. $\Delta_{\mathrm{r}} \mathrm{G}^{\theta}-\mathrm{T}(300-1200 \mathrm{~K})$ relationship for possible reactions during the roasting of pyrite.

\section{Thermodynamic Behaviours for the Roasting of Pyrite}

Based on the preliminary analysis of chemical reactions that may occur during the pyrite roasting, a better understanding is allowed by a further thermodynamic analysis for the processes of pyrolysis, oxidation by $\mathrm{O}_{2}$ and reduction by $\mathrm{C} / \mathrm{CO}$. 


\subsection{Pyrolysis of Pyrite}

A number of studies on the pyrolysis of pyrite $[21,25]$ have demonstrated that the resultants are pyrrhotite $\left(\mathrm{Fe}_{1-x} \mathrm{~S}\right)$ and sulphur vapour $\left(\mathrm{S}_{2}\right)$ as shown in Equation (46):

$$
2(1-x) \cdot \mathrm{FeS}_{2}=2 \mathrm{Fe}_{1-x} \mathrm{~S}+(1-2 x) \cdot \mathrm{S}_{2}(\mathrm{~g}) ;(0 \leq x \leq 0.223)
$$

There are various allotropes of elemental sulphur that can be represented by $S_{m}$ with $m$ varying from 1 to 8 or higher. Hu et al. [26] have pointed out that the sulphur vapour from the thermal decomposition of pyrite mainly occurs as $\mathrm{S}_{2}$. Similarly, pyrrhotite $\mathrm{Fe}_{1-x} \mathrm{~S}$ can be $\mathrm{FeS}, \mathrm{Fe}_{11} \mathrm{~S}_{12}, \mathrm{Fe}_{10} \mathrm{~S}_{11}$, $\mathrm{Fe}_{9} \mathrm{~S}_{10}$ or $\mathrm{Fe}_{7.016} \mathrm{~S}_{8}$ (i.e., $\mathrm{Fe}_{0.875} \mathrm{~S}$ ), but a wide range of studies $[16,18]$ have suggested that the most common forms of $\mathrm{Fe}_{1-x} \mathrm{~S}$ are $\mathrm{Fe}_{0.875} \mathrm{~S}$ and $\mathrm{FeS}$. So $\mathrm{Fe}_{0.875} \mathrm{~S} / \mathrm{FeS}$ and $\mathrm{S}_{2}$ were considered as the main resultants for the pyrite pyrolysis, which had also been adopted as discussed in Section 2. Based on the above, the relevant mechanism for the pyrolysis of pyrite was analysed in detail.

According to the pyrolysis reactions (Equations (1) and (2)), the equilibrium constant $\left(\ln K^{\theta}\right)$ could be obtained, that is, $\ln \mathrm{K}^{\theta}=\ln \left\{\left[\mathrm{P}_{\mathrm{S} 2} / \mathrm{P}^{\theta}\right]^{v}\right\}$ ( $v$ is the stoichiometric ratio of gaseous $\mathrm{S}_{2}$ ). After taking $\ln \mathrm{K}^{\theta}$ into the Van't Hoff equation of $\Delta_{\mathrm{r}} \mathrm{G}^{\theta}=-\mathrm{RT} \ln \mathrm{K}^{\theta}$, the relationship between $\mathrm{P}_{\mathrm{S} 2}$ and temperature was presented as $\mathrm{P}_{\mathrm{S} 2}=\mathrm{P}^{\theta}\left\{\exp \left[\Delta_{\mathrm{r}} \mathrm{G}^{\theta} /(-v \mathrm{RT})\right]\right\}$.

The variation of $\mathrm{P}_{\mathrm{S} 2}$ with $\mathrm{T}$ for the pyrite pyrolysis is clearly shown in Figure 2. With the formation of $S_{2}$ and pyrrhotite, the thermal decomposition of pyrite occurs only at relatively high temperatures. Thermodynamically, the formation of $\mathrm{Fe}_{0.875} \mathrm{~S}(>\sim 800 \mathrm{~K})$ is easier than that of $\mathrm{FeS}(>\sim 900 \mathrm{~K})$. As the temperature is higher than $895 \mathrm{~K}$ and $1020 \mathrm{~K}$, with a pronounced increase of $\mathrm{P}_{\mathrm{S} 2}(\geq 100 \mathrm{kPa})$ the pyrite decomposes markedly to $\mathrm{Fe}_{0.875} \mathrm{~S}$ and FeS, respectively. This is consistent with the analysis in Section 2 and previous experimental observations $[11,12,27]$. In addition, the formed $\mathrm{FeS}$ and $\mathrm{Fe}_{0.875} \mathrm{~S}$ may further decompose to Fe and $S_{2}$ as shown by Equations (47) and (48) (Table 2). The relationship formulas between $\mathrm{P}_{\mathrm{S} 2}$ and $\mathrm{T}$ are also listed in Table 2. The further pyrolysis of pyrrhotite is, however, very difficult since the calculated $\mathrm{P}_{\mathrm{S} 2}$ for the pyrolysis of $\mathrm{Fe}_{0.875} \mathrm{~S}$ and $\mathrm{FeS}$ is separately as low as $5.554 \times 10^{-7} \mathrm{kPa}$ and $4.9383 \times 10^{-4} \mathrm{kPa}$ even at a high temperature of $1200 \mathrm{~K}$.

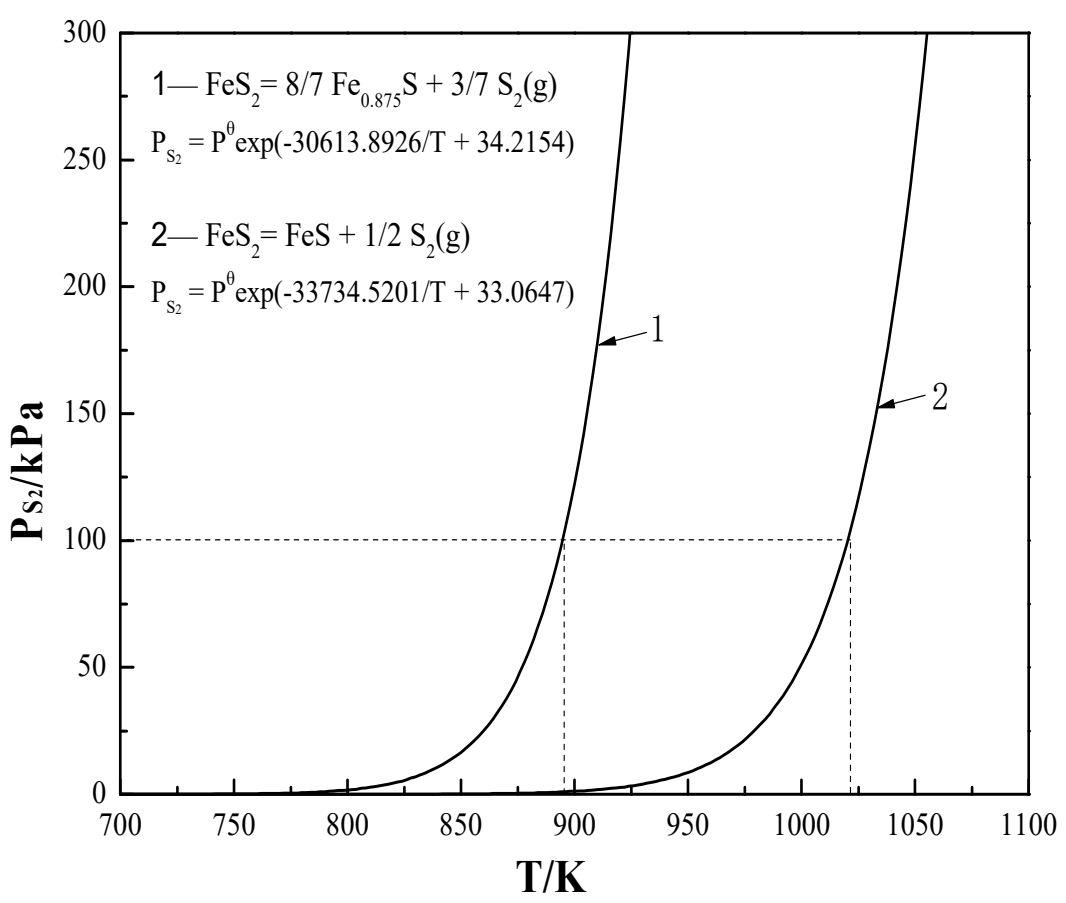

Figure 2. Relationship of $\mathrm{P}_{\mathrm{S} 2}$ and $\mathrm{T}$ during the pyrolysis of pyrite. 
Table 2. Pyrolysis of $\mathrm{FeS}$ and $\mathrm{Fe}_{0.875} \mathrm{~S}$ and the corresponding relationship between $\mathrm{P}_{\mathrm{S} 2}$ and $\mathrm{T}$.

\begin{tabular}{ccc}
\hline Reaction & Relationship Formula of $\mathbf{P}_{\mathrm{S} 2}$ and T & No. \\
\hline $\mathrm{Fe}_{0.875} \mathrm{~S}=7 / 8 \mathrm{Fe}+1 / 2 \mathrm{~S}_{2}(\mathrm{~g})$ & $\mathrm{P}_{\mathrm{S} 2}=\mathrm{P}^{\theta} \exp (-39746.2232 / \mathrm{T}+14.1132)$ & $(47)$ \\
$\mathrm{FeS}=\mathrm{Fe}+1 / 2 \mathrm{~S}_{2}(\mathrm{~g})$ & $\mathrm{P}_{\mathrm{S} 2}=\mathrm{P}^{\theta} \exp (-31989.5959 / \mathrm{T}+14.4395)$ & $(48)$ \\
\hline
\end{tabular}

Pyrrhotite, as a typical pyrolysis product from pyrite, is also often found from the oxidative roasting of pyrite. Its formation is largely affected by the heterogeneous atmosphere, the heating effect of reactions and the particle size of pyrite. This can be illuminated from the aspects of thermodynamics and kinetics as follows:

(i) A partial inert atmosphere may be formed due to the restricted mass transfer of $\mathrm{O}_{2}$, so pyrrhotite can be generated from the pyrolysis of pyrite (Equations (1) and (2)). In an oxidizing atmosphere where $\mathrm{O}_{2}$ is freely accessible, pyrite can also be oxidized to pyrrhotite as shown by Equations (4) and (5). As mentioned in Section 2, with $S_{2}$ being an intermediate, pyrrhotite can be easily formed from the oxidation of pyrite by $\mathrm{O}_{2}$ at much lower temperatures compared to the pyrolysis of pyrite.

(ii) The thermal decomposition of pyrite is endothermic whilst the oxidation of pyrite by $\mathrm{O}_{2}$ is exothermic. In particular, the oxidation of intermediate $\mathrm{S}_{2}$ by $\mathrm{O}_{2}$ (Equation (3)) is typically accompanied with the release of a large amount of heat. The exothermic effect may cause partial overhigh temperatures that favour the pyrite pyrolysis under a partial inert atmosphere.

(iii) During the roasting of pyrite particles, the $S_{2}$ desorption from the pyrite surface has been suggested to be the rate-controlling step for pyrite pyrolysis [20]. In an oxidative roasting process, the formation of pyrrhotite likely conforms to a shrinking-core reaction model with pyrite as the core and pyrrhotite as the shell [22]. In addition, the rate of pyrrhotite formation from the pyrite oxidation by $\mathrm{O}_{2}$ is two orders of magnitude larger than that from the pyrite pyrolysis [22]. This is possibly due to the fact that in an $\mathrm{O}_{2}$-containing atmosphere, once the intermediate $\mathrm{S}_{2}$ makes contact with $\mathrm{O}_{2}$, it is easily oxidized as volatile $\mathrm{SO}_{2}$, which will rapidly decrease the $\mathrm{S}_{2}$ concentration in the reaction interface of pyrite and thus improve the formation of pyrrhotite. At moderate $\mathrm{O}_{2}$ concentrations, the produced pyrrhotite was found to be porous, which is beneficial to the diffusion of $\mathrm{O}_{2}$ and $\mathrm{SO}_{2}$ [21].

Oxygen can expedite the formation of pyrrhotite, but under relatively high $\mathrm{O}_{2}$ concentrations, the nonoxidized pyrrhotite continues to oxidize or the pyrite is oxidized by $\mathrm{O}_{2}$ without forming pyrrhotite as an intermediate. As described in Section 2, the oxidation products may be iron oxides or iron sulphates and $\mathrm{SO}_{2}$. The oxidation of pyrite by $\mathrm{O}_{2}$ was further discussed in detail as will be shown in the following section.

\subsection{Oxidation of Pyrite by Oxygen}

\subsubsection{Phase Transformation of Pyrite Roasting}

During the pyrite oxidation by $\mathrm{O}_{2}, \mathrm{FeS}_{2}$ may be converted to various iron phases that include sulphides $\left(\mathrm{Fe}_{0.875} \mathrm{~S} / \mathrm{FeS}\right)$, oxides $\left(\mathrm{Fe}_{3} \mathrm{O}_{4} / \mathrm{Fe}_{2} \mathrm{O}_{3}\right)$ and sulphates $\left(\mathrm{FeSO}_{4} / \mathrm{Fe}_{2}\left(\mathrm{SO}_{4}\right)_{3}\right)$ as mentioned in Section 2 (Equations (4)-(24)). In addition, the produced $\mathrm{SO}_{2}$ changes the roasting atmosphere and hence has a great impact on the phase transformations for pyrite roasting.

The equilibrium constant $\left(\ln \mathrm{K}^{\theta}\right)$ from the relevant oxidation reactions could be attained, that is, $\ln K^{\theta}=\ln \left\{\left[\mathrm{P}_{\mathrm{SO} 2} / \mathrm{P}^{\theta}\right]^{( \pm v 1)} /\left[\mathrm{P}_{\mathrm{O} 2} / \mathrm{P}^{\theta}\right]^{v 2}\right\}$, where $\pm v_{1}\left(-v_{1}\right.$ for the reactant and $+v_{1}$ for the resultant $)$ and $v_{2}$ are the stoichiometric ratio of $\mathrm{SO}_{2}$ and $\mathrm{O}_{2}$, respectively. Based on $\Delta_{\mathrm{r}} \mathrm{G}^{\theta}=-\mathrm{RT} \ln \mathrm{K}^{\theta}$, the relationship between $\mathrm{P}_{\mathrm{SO} 2} / \mathrm{P}^{\theta}$ and $\mathrm{P}_{\mathrm{O} 2} / \mathrm{P}^{\theta}$ was rearranged as $\lg \left[\mathrm{P}_{\mathrm{SO} 2} / \mathrm{P}^{\theta}\right]=\left[v_{2} /\left( \pm v_{1}\right)\right]\left\{\lg \left[\mathrm{P}_{\mathrm{O} 2} / \mathrm{P}^{\theta}\right]\right\}+\left[\Delta_{\mathrm{r}} \mathrm{G}^{\theta} /(-\mathrm{RT})\right] /\left[\left( \pm v_{1}\right) \ln 10\right]$. At a constant temperature, the isothermal predominance areas for the $\mathrm{Fe}-\mathrm{S}-\mathrm{O}$ system (Figure 3 ) were determined as a function of $\lg \left[\mathrm{P}_{\mathrm{SO} 2} / \mathrm{P}^{\theta}\right]$ and $\lg \left[\mathrm{P}_{\mathrm{O} 2} / \mathrm{P}^{\theta}\right]$. 

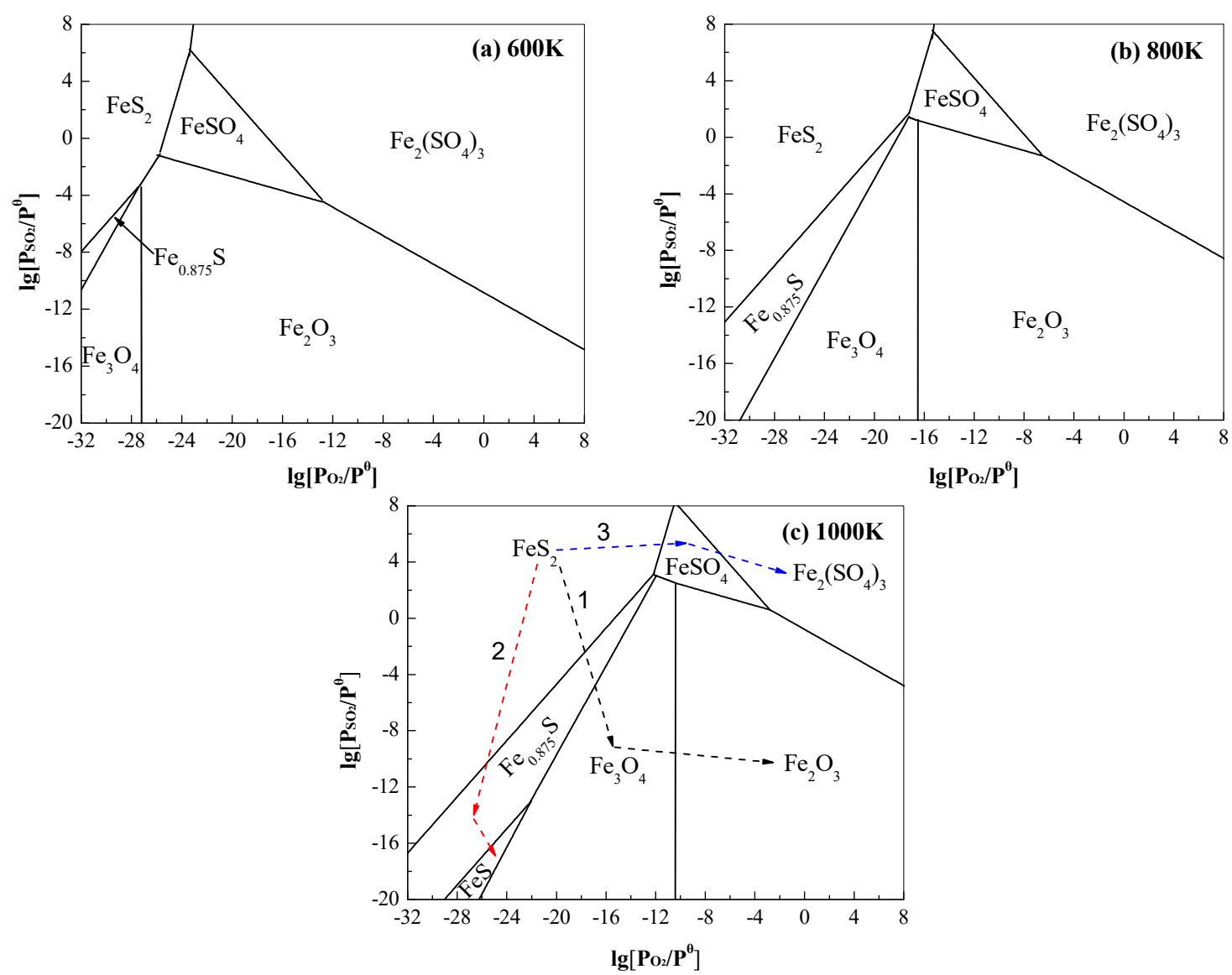

Figure 3. Isothermal predominance area of the $\mathrm{Fe}-\mathrm{S}-\mathrm{O}$ system as a function of $\lg \left[\mathrm{P}_{\mathrm{SO} 2} / \mathrm{P}^{\theta}\right]$ and $\lg \left[\mathrm{P}_{\mathrm{O} 2} / \mathrm{P}^{\theta}\right]$ at a temperature of (a) $600 \mathrm{~K}$, (b) $800 \mathrm{~K}$ and (c) $1000 \mathrm{~K}$.

Figure 3 shows that, in a wide range of $\lg \left[\mathrm{P}_{\mathrm{SO} 2} / \mathrm{P}^{\theta}\right](=-20-8)$ and $\lg \left[\mathrm{P}_{\mathrm{O} 2} / \mathrm{P}^{\theta}\right](=-32-8)$, an increasing temperature from $600 \mathrm{~K}$ to $1000 \mathrm{~K}$ observably enlarges the stability regions of $\mathrm{FeS}_{2}, \mathrm{Fe}_{0.875} \mathrm{~S} / \mathrm{FeS}$ and $\mathrm{Fe}_{3} \mathrm{O}_{4}$ but shrinks those of $\mathrm{Fe}_{2} \mathrm{O}_{3}, \mathrm{FeSO}_{4}$ and $\mathrm{Fe}_{2}\left(\mathrm{SO}_{4}\right)_{3}$. The stability area of $\mathrm{FeS}$ appears only as the temperature increases to $1000 \mathrm{~K}$ (Figure $3 \mathrm{c}$ ). At a constant temperature, low $\mathrm{P}_{\mathrm{O} 2}$ is shown to benefit the stability of iron sulphides while iron oxides and sulphates tend to be stable under relatively high $\mathrm{P}_{\mathrm{O} 2}$. Under low $\mathrm{P}_{\mathrm{O} 2}$, pyrite is stable at relatively high $\mathrm{P}_{\mathrm{SO} 2}$; the decrease of $\mathrm{P}_{\mathrm{SO} 2}$ favours the existence of pyrrhotite. When $\mathrm{P}_{\mathrm{O} 2}$ is relatively high, a high $\mathrm{P}_{\mathrm{SO} 2}$ obviously benefits the occurrence of iron sulphates. On the contrary, low $\mathrm{P}_{\mathrm{SO} 2}$ is evidently advantageous to stabilise the iron oxides.

Depending upon the reaction conditions, thermodynamically, pyrite may experience three routes (1-3 marked in Figure 3c) of phase transformation during its roasting process. (i) Under insufficient $\mathrm{SO}_{2}$, pyrite can be directly oxidized with enough $\mathrm{O}_{2}$ to iron oxides (Equations (7) and (8)) via Route 1. This is consistent with the research results $[10,12,13,27]$ showing that only hematite is observed during the roasting of pyrite in an air atmosphere. (ii) When $\mathrm{SO}_{2}$ and $\mathrm{O}_{2}$ are both inadequate, pyrite is oxidized to pyrrhotite (Equations (4) and (5)) by Route 2 as discussed in Section 3.1. (iii) In the presence of sufficient $\mathrm{SO}_{2}$ and $\mathrm{O}_{2}$, pyrite can be directly transformed to iron sulphates (Equations (14) and (15)) through Route 3, which is also supported by previous experimental studies [10-12].

The practical roasting process of pyrite is complex due mainly to the influence of mineral particle size and heterogeneous atmosphere. Taking the most common roasting of pyrite in excess of air/oxygen for an example, $\mathrm{O}_{2}$ is easily accessible to the surface of the pyrite particle, so iron oxides can be produced via Route 1. The diffusion of $\mathrm{O}_{2}$ into the interior of pyrite, however, is not easy due to the resistance from the outer layer of the particle. Consequently, an inert or weak $\mathrm{O}_{2}$-containing atmosphere is formed, and hence the particle nucleus tends to decompose as pyrrhotite via Route 2. When the generated pyrrhotite contacts sufficient $\mathrm{O}_{2}$, it can be further oxidized to iron oxides. 
Thus, a complex route of $\mathrm{FeS}_{2} \rightarrow \mathrm{Fe}_{0.875} \mathrm{~S} / \mathrm{FeS}$ (intermediates) $\rightarrow \mathrm{Fe}_{3} \mathrm{O}_{4} / \mathrm{Fe}_{2} \mathrm{O}_{3}$ occurs during the pyrite roasting, which is consistent with a number of studies $[10,11,14]$. Similarly, during the sulphating roasting of pyrite, the pyrrhotite and/or iron oxides can also be produced as intermediates.

\subsubsection{Desulphurization of Pyrite to Iron Oxides}

Refractory auriferous pyrites have been extensively roasted to porous calcines (iron oxides) in order to expose the enclosed gold [9]. This roasting process is often accompanied by sintering and some side-reactions of the sulphation of iron oxides (Equations (20)-(23)). It has been suggested from Section 3.2.1 and many other studies [28-35] that the desulphurization of pyrite and sulphation of iron oxides are largely determined by the roasting temperature and atmosphere. As shown in Figure $3 \mathrm{a}-\mathrm{c}$, under a certain range of $\lg \left[\mathrm{P}_{\mathrm{SO} 2} / \mathrm{P}^{\theta}\right]$ and $\lg \left[\mathrm{P}_{\mathrm{O} 2} / \mathrm{P}^{\theta}\right]$, the increase of temperature (600-1000 K) destabilises the iron sulphates by significantly reducing their stability areas, but high temperatures also easily cause sintering and hence the secondary encapsulation of gold. Assuming that $\mathrm{P}_{\mathrm{SO} 2} / \mathrm{P}^{\theta}$ was constant, the effects of temperature and oxygen on the roasting of pyrite were further investigated.

We could also attain a relationship formula of $\lg \left[\mathrm{P}_{\mathrm{O} 2} / \mathrm{P}^{\theta}\right]=\Delta_{\mathrm{r}} \mathrm{G}^{\theta} /\left[\left(v_{2} \ln 10\right) \mathrm{RT}\right]+\left[\left( \pm v_{1}\right) / v_{2}\right] \lg \left[\mathrm{P}_{\mathrm{SO} 2} / \mathrm{P}^{\theta}\right]$ for the desulphurization reactions of iron sulphides (Equations (7)-(12)) and sulphation reactions of iron oxides (Equations (20)-(23)) according to the equilibrium constant $\ln \mathrm{K}^{\theta}=\ln \left\{\left[\mathrm{P}_{\mathrm{SO} 2} / \mathrm{P}^{\theta}\right]^{ \pm v 1)} /\left[\mathrm{P}_{\mathrm{O} 2} / \mathrm{P}^{\theta}\right]^{v 2}\right\}$ and $\Delta_{\mathrm{r}} \mathrm{G}^{\theta}=-\mathrm{RT} \ln \mathrm{K}^{\theta}$. At a constant of $\mathrm{P}_{\mathrm{SO} 2} / \mathrm{P}^{\theta}(0.05$ or 0.5$)$, the effects of $\mathrm{T}$ and $\mathrm{O}_{2}$ on the pyrite roasting as a function of $\lg \left[\mathrm{P}_{\mathrm{O} 2} / \mathrm{P}^{\theta}\right]$ and $\mathrm{T}$ are shown in Figure 4.
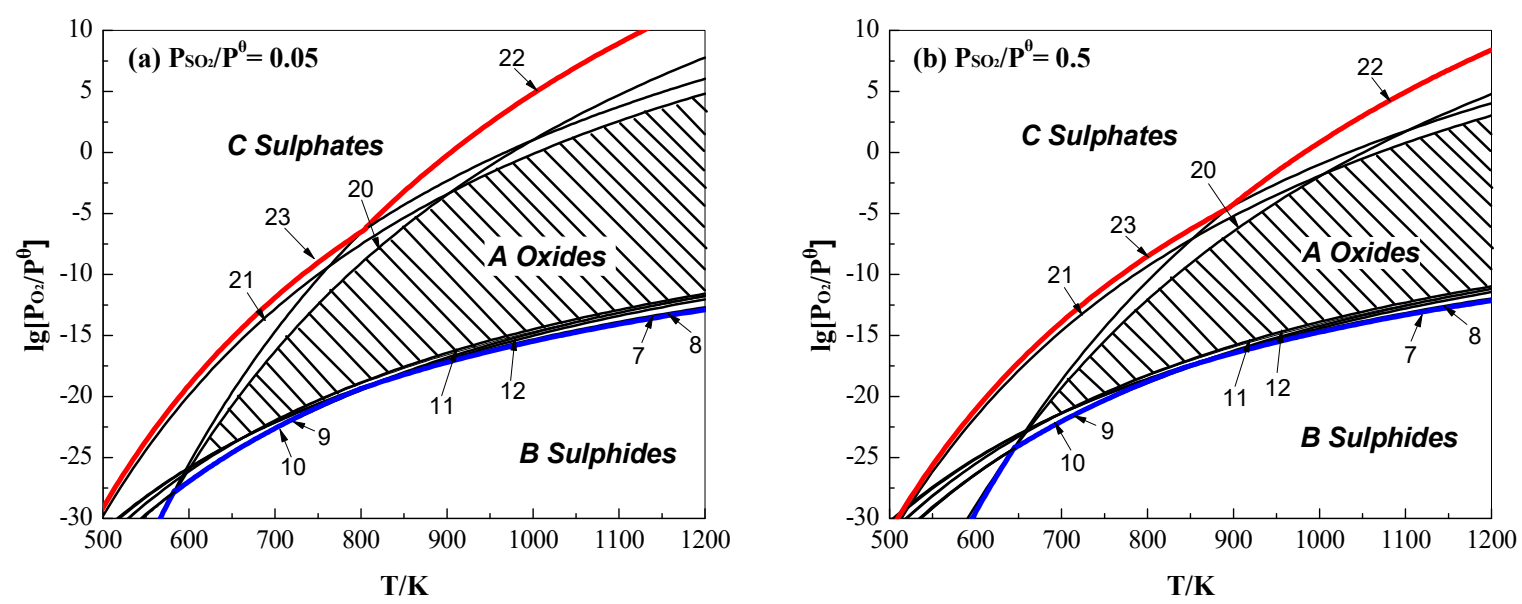

Figure 4. Effects of $\mathrm{O}_{2}$ and $\mathrm{T}$ on the roasting of pyrite as a function of $\lg \left[\mathrm{P}_{\mathrm{O} 2} / \mathrm{P}^{\theta}\right]$ and $\mathrm{T}$ under $(\mathbf{a}) \mathrm{P}_{\mathrm{SO} 2} / \mathrm{P}^{\theta}$ $=0.05$ and $(\mathbf{b}) \mathrm{P}_{\mathrm{SO} 2} / \mathrm{P}^{\Theta}=0.5$.

As seen in Figure 4, iron oxides are produced from the oxidation of pyrite and its pyrolysis product, that is, pyrrhotite in the areas above Lines 7-12 (i.e., Equations (7)-(12)) and also from the decomposition of iron sulphates in the areas below Lines 20-23 (i.e., Equations (20)-(23)). As a result, an intersected area (i.e., shaded Area $A$ ) was obtained that represents the stability area of iron oxides. Similarly, iron sulphides and sulphates are thermodynamically stable in Area $B$ and Area $C$, respectively. Comparing Figure $4 a$ with Figure $4 b$, the decrease of $\mathrm{P}_{\mathrm{SO} 2} / \mathrm{P}^{\theta}$ enlarges Area $A$ and hence improves the thermodynamical stability of iron oxides, which is consistent with the results in Figure 3. As seen from Area $A$, an increasing $\mathrm{T}$ and $\mathrm{O}_{2}$ partial pressure appears to favour the formation of iron oxides. Thermodynamically, the reaction conditions of $\mathrm{O}_{2}$ partial pressure (or concentration) and $\mathrm{T}$ should be controlled within Area $A$ to ensure the roasting of pyrite to iron oxides. In practice, besides minimizing the pressure or concentration of $\mathrm{SO}_{2}$, the temperature should be not too high in order to avoid the occurrence of sintering during roasting. 


\subsection{Effect of Carbon on Pyrite Roasting}

As analysed in Section 2, carbon can impact the roasting of pyrite by the reduction from $\mathrm{C} / \mathrm{CO}$ (Equations (35)-(44)). The reduction reactions may proceed by the direct reduction of $C$ or the indirect reduction of $\mathrm{CO}$ produced from the gasification of $\mathrm{C}$ (Equation (31)). It is assumed that the direct reduction by $\mathrm{C}$ during the roasting process was negligible due mainly to the limited solid-solid reaction interfaces. Therefore, $\mathrm{C}$ influences the pyrite roasting mainly in a two-step way of firstly the gasification of $\mathrm{C}$ to $\mathrm{CO}$ and then the reducing action of $\mathrm{CO}$.

Using the same calculation method as mentioned before, based on $\ln \mathrm{K}^{\theta}=\ln \left\{\left[\mathrm{P}_{\mathrm{SO} 2} / \mathrm{P}^{\theta}\right]^{\nu 1}\right.$ $\left.\left[\mathrm{P}_{\mathrm{CO} 2} / \mathrm{P}_{\mathrm{CO}}\right]^{\nu 2}\right\}\left(v_{1}\right.$ and $v_{2}$ are the stoichiometric ratios of $\mathrm{SO}_{2}$ and $\mathrm{CO}_{2} / \mathrm{CO}$, respectively) and $\Delta_{\mathrm{r}} \mathrm{G}^{\theta}$ $=-\mathrm{RT} \ln \mathrm{K}^{\theta}$, the relationship formula of $\lg \left[\mathrm{P}_{\mathrm{CO}} / \mathrm{P}_{\mathrm{CO} 2}\right]=\Delta_{\mathrm{r}} \mathrm{G}^{\theta} /\left[\left(v_{2} \ln 10\right) \mathrm{RT}\right]+\left(v_{1} / v_{2}\right) \lg \left[\mathrm{P}_{\mathrm{SO} 2} / \mathrm{P}^{\theta}\right]$ was obtained for the relevant reduction reactions. Under a constant $\mathrm{P}_{\mathrm{SO} 2} / \mathrm{P}^{\theta}(=0.05)$, the effect of $\mathrm{C}$ on the pyrite roasting as a function of $\lg \left[\mathrm{P}_{\mathrm{CO}} / \mathrm{P}_{\mathrm{CO} 2}\right]$ and $\mathrm{T}$ is shown in Figure 5.

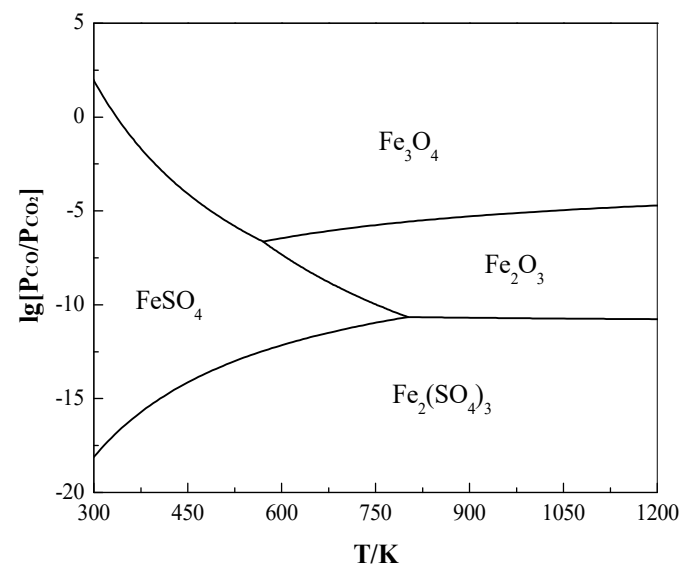

Figure 5. Effect of $\mathrm{C}$ on the roasting of pyrite as a function of $\lg \left[\mathrm{P}_{\mathrm{CO}} / \mathrm{P}_{\mathrm{CO} 2}\right]$ and $\mathrm{T}$ under $\mathrm{P}_{\mathrm{SO} 2} / \mathrm{P}^{\theta}=0.05$.

It is clearly shown in Figure 5 that the iron sulphates are readily transformed to the iron oxides due to the reduction of $\mathrm{CO}$ at very low levels of $\mathrm{P}_{\mathrm{CO}} / \mathrm{P}_{\mathrm{CO} 2}$. When $\mathrm{T}$ is lower than $\sim 800 \mathrm{~K}, \mathrm{FeSO}_{4}$ easily changes to $\mathrm{Fe}_{3} \mathrm{O}_{4}$ or $\mathrm{Fe}_{2} \mathrm{O}_{3}$ with an increasing T. The required $\mathrm{P}_{\mathrm{CO}} / \mathrm{P}_{\mathrm{CO} 2}$ for this transformation is reduced from $10^{-6}$ at $500 \mathrm{~K}$ to $10^{-10.6}$ at $800 \mathrm{~K}$. In addition, $\mathrm{CO}$ is liable to reduce $\mathrm{Fe}_{2}\left(\mathrm{SO}_{4}\right)_{3}$ to $\mathrm{FeSO}_{4}$ once $\mathrm{P}_{\mathrm{CO}} / \mathrm{P}_{\mathrm{CO} 2}$ is higher than $10^{-18}-10^{-10.6}$ and then further reduce from $\mathrm{FeSO}_{4}$ to $\mathrm{Fe}_{3} \mathrm{O}_{4} / \mathrm{Fe}_{2} \mathrm{O}_{3}$. As T exceeds $\sim 800 \mathrm{~K}, \mathrm{Fe}_{2}\left(\mathrm{SO}_{4}\right)_{3}$ tends to be more thermodynamically stable than $\mathrm{FeSO}_{4}$, but it is apt to be directly oxidized to $\mathrm{Fe}_{2} \mathrm{O}_{3}$ at $\mathrm{P}_{\mathrm{CO}} / \mathrm{P}_{\mathrm{CO} 2}>\sim 10^{-10}$. Therefore, during the desulphurizing roasting of pyrite to iron oxides, the presence of a certain amount of carbon is likely conducive to prevent the formation of the by-products of iron sulphates, which is preliminarily verified by a recent research on the roasting of a refractory carbonaceous sulphide gold concentrate [36].

\section{Conclusions}

The roasting behaviour of pyrite under different temperatures and atmospheres is analysed by a series of thermodynamic calculations. The $\Delta_{\mathrm{r}} \mathrm{G}^{\theta}-\mathrm{T}(300-1200 \mathrm{~K})$ relationship suggests that the pyrite roasting can include pyrolysis, oxidation, sulphation and reduction reactions under different atmospheres. In an inert atmosphere, the pyrolysis of pyrite to pyrrhotite spontaneously proceeds only at a relatively high $\mathrm{T}(>900-1000 \mathrm{~K})$. Pyrrhotite can also be formed in an $\mathrm{O}_{2}$-containing atmosphere. However, comparing with the pyrite pyrolysis, the formation of pyrrhotite from oxidation can occur at much lower temperatures due mainly to the easy oxidation of $\mathrm{S}_{2}$ by $\mathrm{O}_{2}$ to $\mathrm{SO}_{2}$. The isothermal predominance areas for the $\mathrm{Fe}-\mathrm{S}-\mathrm{O}$ system indicate that pyrite may experience three routes of the phase transformation during its roasting. Firstly, pyrite is directly oxidized with sufficient $\mathrm{O}_{2}$ to iron oxides under low levels of $\mathrm{P}_{\mathrm{SO} 2} / \mathrm{P}^{\theta}$ (i.e., Route 1: $\mathrm{FeS}_{2} \rightarrow \mathrm{Fe}_{3} \mathrm{O}_{4} / \mathrm{Fe}_{2} \mathrm{O}_{3}$ ). Secondly, pyrite is oxidized to pyrrhotite under low levels of $\mathrm{P}_{\mathrm{O} 2} / \mathrm{P}^{\theta}$ and $\mathrm{P}_{\mathrm{SO} 2} / \mathrm{P}^{\theta}$ (i.e., Route 2: $\mathrm{FeS}_{2} \rightarrow \mathrm{Fe}_{0.875} \mathrm{~S} / \mathrm{FeS}$ ). 
Thirdly, pyrite is oxidized to iron sulphates under high levels of $\mathrm{P}_{\mathrm{O} 2} / \mathrm{P}^{\theta}$ and $\mathrm{P}_{\mathrm{SO} 2} / \mathrm{P}^{\theta}$ (i.e., Route 3: $\left.\mathrm{FeS}_{2} \rightarrow \mathrm{FeSO}_{4} / \mathrm{Fe}_{2}\left(\mathrm{SO}_{4}\right)_{3}\right)$. The reaction conditions of $\mathrm{P}_{\mathrm{O} 2} / \mathrm{P}^{\theta}$ and $\mathrm{T}$ for stabilising iron oxides (Area $A$ ), sulphides (Area $B$ ) and sulphates (Area $C$ ) could also be obtained for the roasting of pyrite. In terms of the desulphurization of pyrite to porous iron oxides, theoretically, an appropriate range of $\mathrm{P}_{\mathrm{O} 2} / \mathrm{P}^{\theta}$ and not too high $\mathrm{T}$ can be chosen from Area $A$ in order to avoid or minimize sintering, which is beneficial to expose the common associated valuable metals such as $\mathrm{Au}$ and $\mathrm{Ag}$, and hence their subsequent leaching. In addition, $\mathrm{C}$ is shown to favour the formation of iron oxides. This is largely attributed to the fact that iron sulphates can be reduced by $\mathrm{CO}$ to iron oxides at very low levels of $\mathrm{P}_{\mathrm{CO}} / \mathrm{P}_{\mathrm{CO} 2}$ such as $\sim 10^{-10.6}$ at $\mathrm{T}>800 \mathrm{~K}$. Therefore, the presence of carbon is likely advantageous to the desulphurizing roasting of carbonaceous pyrite with $\mathrm{O}_{2}$ to iron oxides.

The actual roasting of pyrite is complicated due mainly to the particle size of pyrite and/or the heterogeneous atmosphere. During the roasting of pyrite in an $\mathrm{O}_{2}$-containing atmosphere, different reactions involving a number of intermediates may take place, which is also well explained from the thermodynamic analysis in this paper with published kinetic research. The thermodynamic results presented in this paper provide a theoretical basis and a tool for the optimization of a specific roasting behaviour of pyrite.

Author Contributions: Y.Z. collected the thermodynamic data; Y.Z. and Q.L. performed the calculations; Y.Z. and X.L. wrote the paper; B.X., Y.Y. and T.J. reviewed it before submission.

Funding: This research was funded by National Natural Science Foundation of China (Grant Nos. 51574284 and 51504293), the Fundamental Research Funds for the Central Universities of Central South University (No. 2017zzts194) and the China Scholarship Council (Grant Nos. 201706370222 and 201606370128).

Acknowledgments: Financial supports from the National Natural Science Foundation of China, the Fundamental Research Funds for the Central Universities of Central South University and the China Scholarship Council are all gratefully acknowledged.

Conflicts of Interest: The authors declare no conflict of interest.

\section{References}

1. Liu, X.; Xu, B.; Min, X.; Li, Q.; Yang, Y.; Jiang, T.; He, Y.; Zhang, X. Effect of pyrite on thiosulfate leaching of gold and the role of ammonium alcohol polyvinyl phosphate (AAPP). Metals 2017, 7, 278. [CrossRef]

2. Li, Q.; Zhang, Y.; Liu, X.; Xu, B.; Yang, Y.; Jiang, T. Improvement of gold leaching from a refractory gold concentrate calcine by separate pretreatment of coarse and fine size fractions. Minerals 2017, 7, 80.

3. Liu, X.; Xu, B.; Yang, Y.; Li, Q.; Jiang, T.; Zhang, X.; Zhang, Y. Effect of galena on thiosulfate leaching of gold. Hydrometallurgy 2017, 171, 157-164. [CrossRef]

4. Frser, K.S.; Whlton, R.H.; Wells, J.A. Processing of refractory gold ores. Miner. Eng. 1991, 4, 1029-1041.

5. Zhou, J.; Gu, Y. Chapter 6: Geometallurgical Characterization and Automated Mineralogy of Gold Ores. In Gold Ore Processing: Project Development and Operations, 2nd ed.; Adams, M.D., Ed.; Elsevier: Oxford, UK, 2016; pp. 95-111.

6. Afenya, P.M. Treatment of carbonaceous refractory gold ores. Miner. Eng. 1991, 4, 1043-1055.

7. De Michelis, I.; Olivieri, A.; Ubaldini, S.; Ferella, F.; Beolchini, F.; Vegli, F. Roasting and chlorine leaching of gold-bearing refractory concentrate: Experimental and process analysis. Int. J. Min. Sci. Technol. 2013, 23, 709-715. [CrossRef]

8. Yang, H.; Liu, Q.; Song, X.; Dong, J. Research status of carbonaceous matter in carbonaceous gold ores and bio-oxidation pretreatment. Trans. Nonferrous Met. Soc. China. 2013, 23, 3405-3411. [CrossRef]

9. Liu, X.; Li, Q.; Zhang, Y.; Jiang, T.; Yang, Y.; Xu, B.; He, Y. Improving gold recovery from a refractory ore via $\mathrm{Na}_{2} \mathrm{SO}_{4}$ assisted roasting and alkaline $\mathrm{Na}_{2} \mathrm{~S}$ leaching. Hydrometallurgy 2019, 185, 133-141. [CrossRef]

10. Dunn, J.G.; De, G.C. The effect of experimental variables on the mechanism of the oxidation of pyrite. Part 1. Oxidation of particles less than $45 \mu \mathrm{m}$ in size. Thermochim. Acta 1989, 145, 115-130. [CrossRef]

11. Dunn, J.G.; De, G.C. The effect of experimental variables on the mechanism of the oxidation of pyrite. Part 2. Oxidation of particles of size 90-125 um. Thermochim. Acta 1989, 155, 135-149. [CrossRef]

12. Jorgensen, F.R.A.; Moyle, F.J. Phases formed during the thermal analysis of pyrite in air. J. Therm. Anal. 1982, 25, 473-485. [CrossRef] 
13. Schorr, J.R.; Everhart, J.O. Thermal behavior of pyrite and its relation to carbon and sulfur oxidation in clays. J. Am. Ceram. Soc. 1969, 52, 351-354. [CrossRef]

14. Prasad, A.; Singru, R.M.; Biswa, A.K. Study of the roasting of pyrite minerals by Mössbauer spectroscopy. Phys. Status Solidi A 1985, 87, 267-271. [CrossRef]

15. Hong, Y.; Fegley, B. The kinetics and mechanism of pyrite thermal decomposition. Berichte der Bunsengesellschaft für physikalische Chemie 1997, 101, 1870-1881. [CrossRef]

16. Waldner, P.; Pelton, A.D. Thermodynamic modeling of the Fe-S system. J. Phase Equilib. Diffus. 2005, 26, 23-38. [CrossRef]

17. Chakraborti, N.; Lynch, D.C. Thermodynamics of roasting arsenopyrite. Metall. Trans. B 1983, 14, $239-251$. [CrossRef]

18. Hoare, I.C.; Hurst, H.J.; Stuart, W.I. Thermal decomposition of pyrite: Kinetic analysis of thermogravimetric data by predictor-corrector numerical methods. J. Chem. Soc., Faraday Trans. 1 1988, 84, 3071-3077. [CrossRef]

19. Barin, I. Thermochemical Data of Pure Substances, 3rd ed.; VCH Verlagsgesellschaft mbH: Weinheim, Germany, 1995.

20. Lambert, J.M.; Simkovich, G.; Walker, P.L. The kinetics and mechanism of the pyrite-to-pyrrhotite Transformation. Metall. Mater. Trans. B 1998, 29, 385-396. [CrossRef]

21. Boyabat, N.; Özer, A.K.; Bayrakceken, S.; Glaboğlu, M.Ş. Thermal decomposition of pyrite in the nitrogen atmosphere. Fuel Process. Technol. 2003, 85, 179-188. [CrossRef]

22. Hansen, J.P.; Jensen, L.S.; Wedel, S.; Dam-Johansen, K. Decomposition and oxidation of pyrite in a fixed-bed reactor. Ind. Eng. Chem. Res. 2003, 42, 4290-4295. [CrossRef]

23. Lv, W.; Yu, D.; Wu, J.; Zhang, L.; Xu, M. The chemical role of $\mathrm{CO}_{2}$ in pyrite thermal decomposition. Proc. Combust. Inst. 2015, 35, 3637-3644. [CrossRef]

24. Aylmore, M.G.; Lincoln, F.J. Mechanochemical milling-induced reactions between gases and sulfide minerals: II. Reactions of $\mathrm{CO}_{2}$ with arsenopyrite, pyrrhotite and pyrite. J. Alloys Compd. 2001, 314, 103-113. [CrossRef]

25. Hu, H.; Chen, Q.; Yin, Z.; Zhang, P. Thermal behaviors of mechanically activated pyrites by thermogravimetry (TG). Thermochim. Acta 2003, 398, 233-240. [CrossRef]

26. Hu, G.; Dam-Johansen, K.; Wedel, S.; Hansen, J.P. Decomposition and oxidation of pyrite. Prog. Energy Combust. Sci. 2006, 32, 295-314. [CrossRef]

27. Bhargava, S.K.; Garg, A.; Subasinghe, N.D. In situ high-temperature phase transformation studies on pyrite. Fuel 2009, 88, 988-993. [CrossRef]

28. Schwab, G.M.; Philinis, J. Reactions of iron pyrite: Its thermal decomposition, reduction by hydrogen and air oxidation. J. Am. Chem. Soc. 1947, 69, 2588-2596. [CrossRef]

29. Eneroth, E.; Koch, C.B. Crystallite size of haematite from thermal oxidation of pyrite and marcasite-Effects of grain size and iron disulphide polymorph. Miner. Eng. 2003, 16, 1257-1267. [CrossRef]

30. Eymery, J.P. On a phase transformation produced by mechanical activation in iron pyrite. Eur. Phys. J. Appl. Phys. 1999, 5, 115-121. [CrossRef]

31. Dunn, J.G.; Gong, W.; Shi, D. A Fourier transform infrared study of the oxidation of pyrite. Thermochim. Acta 1992, 208, 293-303. [CrossRef]

32. Dunn, J.G.; Gong, W.; Shi, D. A Fourier transform infrared study of the oxidation of pyrite. The influences of experimental variables. Thermochim. Acta 1993, 215, 247-254. [CrossRef]

33. Komraus, J.; Popiel, E.; Mocek, R. Chemical transformations of ferruginous minerals during the process of oxidation of hard coal. Hyperfine Interact 1990, 58, 2589-2592. [CrossRef]

34. Allen, G.C.; Paul, M. Chemical characterization of transition metal spinel-type oxides by infrared spectroscopy. Appl. Spectrosc. 1995, 49, 451-458. [CrossRef]

35. Eymery, J.P.; Ylli, F. Study of a mechanochemical transformation in iron pyrite. J. Alloys Compd. 2000, 298, 306-309. [CrossRef]

36. Liu, X.; Li, Q.; Zhang, Y.; Jiang, T.; Yang, Y.; Xu, B.; He, Y. Simultaneous removal of S and As from a refractory gold ore in a single stage $\mathrm{O}_{2}$-enriched roasting process. Metall. Mater. Trans. B 2019, in press.

(C) 2019 by the authors. Licensee MDPI, Basel, Switzerland. This article is an open access article distributed under the terms and conditions of the Creative Commons Attribution (CC BY) license (http://creativecommons.org/licenses/by/4.0/). 